\title{
CAVIN3 Gene
}

National Cancer Institute

\section{Source}

National Cancer Institute. CAVIN3 Gene. NCI Thesaurus. Code C115007.

This gene plays a role in circadian rhythm pathways, caveolae formation and protein kinase $\mathrm{C}$ binding. 